\title{
Incorporation of Sulfur in an Optimized Ladle Steelmaking Slag
}

\author{
Filippos PATSIOGIANNIS and Uday B. PAL
}

Department of Materials Science and Engineering, Massachusetts Institute of Technology, 77 Massachusetts Avenue, Cambridge, MA 02139, USA.

(Received on August 28, 1995; accepted in final form on November 29, 1995)

\begin{abstract}
$\mathrm{CaO}-\mathrm{Al}_{2} \mathrm{O}_{3}-\mathrm{SiO}_{2}=50-42-8 \mathrm{wt} \%$ eutectic slags, similar in composition to a secondary steelmaking slag, containing different amounts of $\mathrm{CaS}$, were heated between 1673-1873 K. DTA was performed. Samples were characterized by EMP and XRD. Four main phases were present: $\mathrm{CaO} \cdot \mathrm{Al}_{2} \mathrm{O}_{3}, 2 \mathrm{CaO} \cdot \mathrm{Al}_{2} \mathrm{O}_{3} \cdot \mathrm{SiO}_{2}$ $2 \mathrm{CaO} \cdot \mathrm{SiO}_{2}$ and $23 \mathrm{CaO} \cdot 14 \mathrm{Al}_{2} \mathrm{O}_{3} \cdot \mathrm{CaS}$ or $22 \mathrm{CaO} \cdot 14 \mathrm{Al}_{2} \mathrm{O}_{3} \cdot 2 \mathrm{CaS}$ products of the reaction of $\mathrm{CaS}$ with $12 \mathrm{CaO} \cdot 7 \mathrm{Al}_{2} \mathrm{O}_{3}$ at $1349( \pm 21) \mathrm{K}$. The sulfur phases crystallized first and the rest of the melt followed the well known $\mathrm{CaO}-\mathrm{Al}_{2} \mathrm{O}_{3}-\mathrm{SiO}_{2}$ phase diagram. For comparison, typical ironmaking and steelmaking slags $\left(\mathrm{CaO}-\mathrm{Al}_{2} \mathrm{O}_{3}-\mathrm{SiO}_{2}=48-12-40 \mathrm{wt} \%\right.$ ) were also utilized to study the incorporation of sulfur in their structure. The resulting phases were all glasses with some non-stoichiometry.
\end{abstract}

KEY WORDS: calcia; alumina; silica; calcium sulfide; crystallization; phases; stability, slag, steelmaking; ladel.

\section{Introduction}

Efficient ladle refining to produce ultra-clean steels are attained only when the steel is treated with a basic, non oxidizing slag. These type of slags are usually created with synthetic slags (fluxes). Synthetic slags must meet the following general requirements: low oxygen potential and melting point, moderate fluidity, and large solubility for the deoxidation product, alumina. The slags having these characteristics can generally be found in the $\mathrm{CaO}-\mathrm{Al}_{2} \mathrm{O}_{3}-\mathrm{SiO}_{2}$ system. Synthetic slags of this type are added to the ladle during or after tapping to refine the steel, retain the transported nonmetallics and serve as a non oxidizing cover for the steel underneath.

On the basis of laboratory experiments which simulated ladle refining operations ${ }^{1-4)}$ the optimum slag for secondary (ladle) refining operations was developed utilizing a flux primarily based on the compound $12 \mathrm{CaO} \cdot 7 \mathrm{Al}_{2} \mathrm{O}_{3}$ (mayenite). ${ }^{5)}$ An eutectic slag, $\mathrm{CaO}$ $\mathrm{Al}_{2} \mathrm{O}_{3}-\mathrm{SiO}_{2}=50-42-8 \mathrm{wt} \%$, similar in composition to the optimized secondary steelmaking slag, was chosen to investigate its capacity for incorporating elements like $\mathrm{Cl}$ and $\mathrm{S}$ in the form of $\mathrm{CaCl}_{2}$ and $\mathrm{CaS}$, respectively, since these are stable compounds and can easily form when lime is used to scavenge these undesirable elements. It can be seen that the primary constituent of the optimized secondary steelmaking slag is mayenite. Mayenite has a body-centered cubic unit cell. The lattice building blocks are $\mathrm{AlO}_{4}$ tetrahedra with three or four oxygens shared. The calcium atoms (twelve atoms, seven coordinated) and one oxygen anion (disordered over twelve equivalent sites) occupy sites within the aluminate framework. The one disordered oxygen anion can be replaced by $\mathrm{O}_{2}^{-}, \mathrm{OH}^{-}, \mathrm{Cl}^{-}, \mathrm{C}^{-}$, and $\mathrm{S}^{2-}$. It ex- plains the term "free" or "active" that have been used to characterize this anion. The optimized synthetic slag based on mayenite had low melting point (1600 K), low viscosity and large solubility for alumina. Mayenite was chosen as the primary phase in the synthetic flux, in order to have chlorine or sulfur substitute the "free" oxygens in the crystal structure of mayenite, thus creating new phases based on the crystal structure of mayenite.

It was found ${ }^{5)}$ that when $\mathrm{CaCl}_{2}$ was added $(1-19 \mathrm{wt} \%)$ to the optimized slag and heated between $1673-1873 \mathrm{~K}$ and cooled only one major chlorine phase $(11 \mathrm{CaO}$. $7 \mathrm{Al}_{2} \mathrm{O}_{3} \cdot \mathrm{CaCl}_{2}$ ) was present. The chlorine phase formed first at $1321( \pm 27) \mathrm{K}$ and remained solid as a separate phase because of its high melting point. The rest of the system upon slow cooling crystallized according to the well known $\mathrm{CaO}-\mathrm{Al}_{2} \mathrm{O}_{3}-\mathrm{SiO}_{2}$ phase diagram. Also when the amount of chlorine was greater than $4.9 \mathrm{wt} \%$, corresponding to $7.7 \mathrm{wt} \% \mathrm{CaCl}_{2}$ in the slag, the chlorine phase constituted a major $(92 \%)$ part by weight of the final slag. The X-ray powder difiraction pattern of the chlorine phase was also determined. It was very similar to the mayenite phase $\left(12 \mathrm{CaO} \cdot 7 \mathrm{Al}_{2} \mathrm{O}_{3}\right)$. The cubic-centered unit cell was found to have a unit cell parameter larger than the one for mayenite. ${ }^{6)}$ This can be explained due to the larger size of the chlorine anion as compared to the oxygen anion which is replaced by chlorine in the structure of mayenite. It is believed that more chlorine phase could be incorporated in the mayenite structure if the trivalent aluminum cations are replaced by tetravalent silicon cations.

In this work the incorporation of sulfur through similar experiments is presented. Once again it was found that the sulfur phase formed first at $1349( \pm 27) \mathrm{K}$ and remained solid as a separate phase because of its high 
melting point. The rest of the system upon slow cooling crystallized according to the well known $\mathrm{CaO}-\mathrm{Al}_{2} \mathrm{O}_{3}-$ $\mathrm{SiO}_{2}$ phase diagram.

For comparison a slag representing a typical ironmaking and steelmaking process, $\mathrm{CaO}-\mathrm{Al}_{2} \mathrm{O}_{3}-\mathrm{SiO}_{2}=$ $48-12-40 \mathrm{wt} \%$ with eutectic at $1583 \mathrm{~K}$, was also chosen to investigate its capacity for incorporating sulfur through similar experiments. A multiplicity of glasses and non stoichiometric phases were present. The amount of sulfur incorporated in this slags was greater than the amount incorporated in the secondary steelmaking slags. However, for this slag system, the mechanism of incorporation of chlorine and sulfur is not clear. In additon when no sulfur was present in the slag, the determination of liquidus and/or solidus temperature was not possible during heating and cooling of the melt. When sulfur was present some transformation temperatures could be determined.

These materials may be used as source materials in the glass, cement and ceramic industries. For example, the raw materials for the manufacture of cement contain suitable proportions of silica, calcium oxide, aluminium oxide and ferric oxide. For the production of Portland cement, slags from the steel industry may be used. For the high alumina cement the ladle steelmaking slags may be used. The chlorine containing slags can be used as accelerators in Portland cement. In addition, they can be used as mill additions in porcelain-enamel slips, as a flocculant in glazes and as a water proofer in concrete.

\section{Experimental}

The homogenized low silica slag, $\mathrm{CaO}-\mathrm{Al}_{2} \mathrm{O}_{3}-\mathrm{SiO}_{2}=$ $50-42-8 \mathrm{wt} \%$, which simulated the optimized secondary steelmaking slag, was used as a master slag for the preparation of the calcium sulfide containing slags in experiments A-F (Table 1). In experiments $\mathrm{G}-\mathrm{K}$ (Table 8) the master slag used had a nominal composition $\mathrm{CaO}-\mathrm{Al}_{2} \mathrm{O}_{3}-\mathrm{SiO}_{2}=48-12-40 \mathrm{wt} \%$ and it simulated a typical ironmaking and steelmaking slag. The master slag was dried for $86400 \mathrm{~s}$ at $673 \mathrm{~K}$. The powders were weighed out and thoroughly mixed inside a high purity $(99.8 \mathrm{wt} \%)$ alumina crucible $\left(3.5 \times 10^{-2} \mathrm{~m}\right.$ diameter and $6.4 \times 10^{-2} \mathrm{~m}$ height). It may be noted that due to some alumina dissolution from the crucible, the composition of the starting slag changed. The crucible was placed on the top of alumina bubbles at the bottom of a one end closed alumina tube $\left(7.62 \times 10^{-2} \mathrm{~m}\right.$ outside dimeter and $6.985 \times 10^{-2} \mathrm{~m}$ inside diameter) and was centered (Fig. 1). An alumina fiber radiation shield was placed on top of the crucible. Two alumina thermocouple protection tubes (one end closed) were placed through the top swage locks, one in the center of the slag and the other (reference) on the side of the crucible at the same height. Callibrated type $\mathrm{S}(\mathrm{Pt}-10 \% \mathrm{Rh})$ thermocouples were used. During the initial heat-up Ar gas was $p$ issed. Then the Ar gas was turned off and the total pressure of the system was maintained at $2.3 \times 10^{3} \mathrm{~Pa}$ above the atmospheric pressure throughout the experiment. This experimental arrangement enhanced the recovery of sulfur. The powders were heated to $1873 \mathrm{~K}\left(1 / 3 \mathrm{~K} \mathrm{~s}^{-1}\right)$
Table 1. Experimental details.

\begin{tabular}{c|ccc}
\hline Experiment & $\begin{array}{c}W_{\mathrm{c}} \\
\left(10^{-3} \mathrm{~kg}\right)\end{array}$ & $\begin{array}{c}W_{\mathrm{m}} \\
\left(10^{-3} \mathrm{~kg}\right)\end{array}$ & $\begin{array}{c}W_{\text {Cas }} \\
\left(10^{-3} \mathrm{~kg}\right)\end{array}$ \\
\hline $\mathrm{A}$ & 61.780 & 34.501 & - \\
$\mathrm{B}$ & 60.575 & 34.697 & - \\
$\mathrm{C}$ & 60.578 & 34.799 & - \\
$\mathrm{D}$ & 52.256 & 34.685 & 0.308 \\
$\mathrm{E}$ & 61.477 & 34.580 & 0.570 \\
$\mathrm{~F}$ & 56.210 & 34.161 & 0.886 \\
$\mathrm{G}$ & 60.672 & 34.842 & - \\
$\mathrm{H}$ & 60.941 & 34.546 & 0.804 \\
$\mathrm{I}$ & 60.186 & 33.247 & 1.757 \\
$\mathrm{~J}$ & 59.528 & 32.503 & 3.597 \\
$\mathrm{~K}$ & 60.200 & 33.900 & 1.094 \\
\hline
\end{tabular}

$W=$ weight, $\mathrm{c}=$ crucible, $\mathrm{m}=$ master slag.

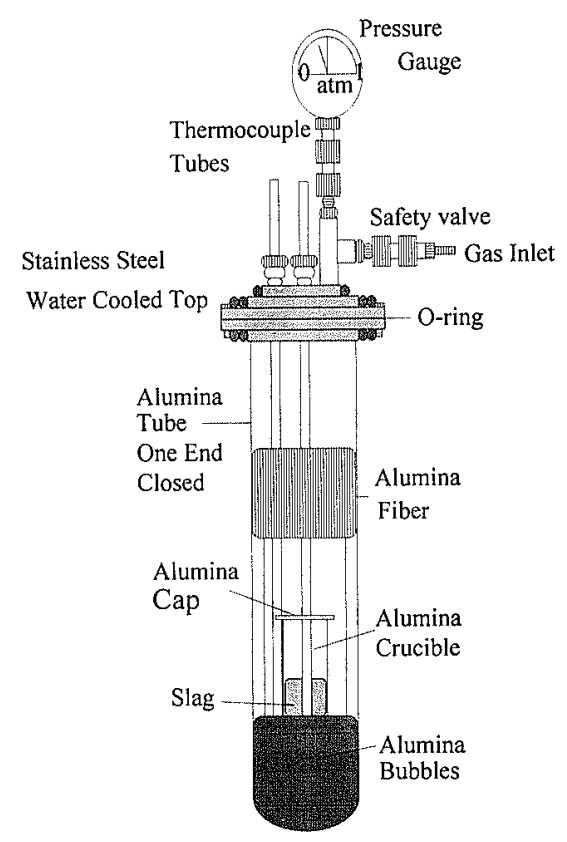

Fig. 1. Schematic of the experimental set-up.

and held for $30 \mathrm{~min}$. Then the system was cooled to

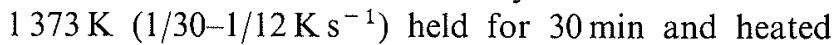
again $\left(1 / 30-1 / 12 \mathrm{~K} \mathrm{~s}^{-1}\right)$. When phase transformation or a reaction occurs the reference thermocouple remains unaffected, but the thermocuple inside the slag experiences either an endothermic or an exothermic effect and a deflection in its steady state temperature cycling is recorded and this was independent of the cycling rate $\left(1 / 30-1 / 12 \mathrm{~K} \mathrm{~s}^{-1}\right)$ that was used. A typical plot is shown in Fig. 2. Therefore, when temperature difference between the reference and the slag sample thermocouple is plotted as a function of the steady state cycling time or the temperature of either the reference or the slag sample, a deflection is associated with phase transformation or a reaction. The measurement accuracy depends on the uniformity of the slag temperature. The melt was finally cooled at $1 / 3 \mathrm{~K} \mathrm{~s}^{-1}$, weighed and a representative section was mounted and polished for the electron microprobe analysis.

In Table 1, the weight of the alumina crucibles used, the weight of the master slag added, and the weight of $\mathrm{CaS}$ added in each experiment are listed. 


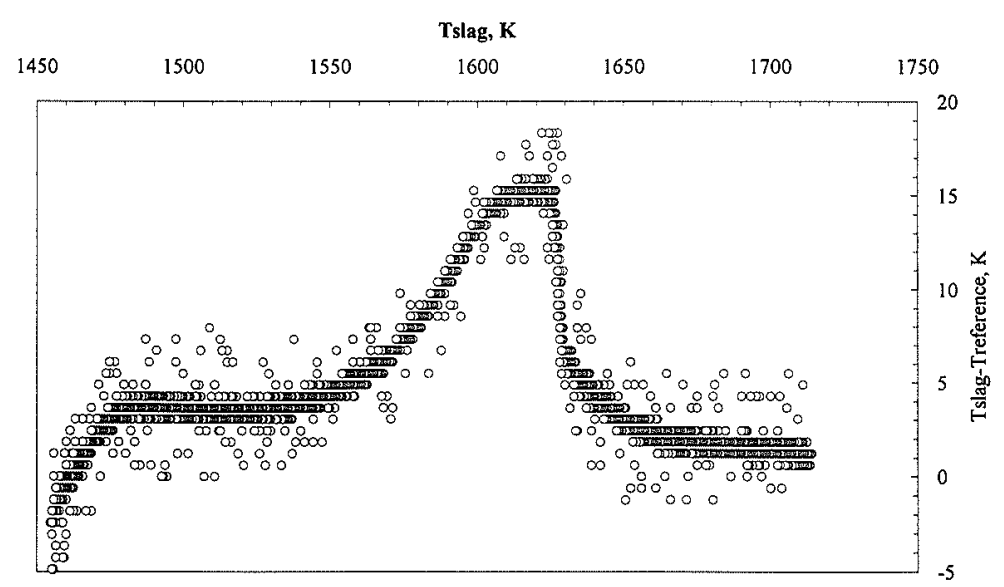

Fig. 2. Typical cooling curve thermogram from the differential thermal analysis experiments.

Table 2. Electron microprobe image analysis of slowly cooled optimized secondary steelmaking slag with CaS.

\begin{tabular}{|c|c|c|c|c|c|c|c|c|c|c|c|c|c|c|c|}
\hline & \multirow[b]{2}{*}{ Phase } & \multirow[b]{2}{*}{ A } & \multicolumn{13}{|c|}{ Experiment } \\
\hline & & & & & B & $\mathrm{C}$ & & & $\mathrm{D}$ & & & $\mathrm{E}$ & & & $\mathrm{F}$ \\
\hline \multicolumn{2}{|r|}{ Name } & \multicolumn{14}{|c|}{ Normalized area of each phase $(\%)$} \\
\hline 1 & $\mathrm{CaAl}_{2} \mathrm{O}_{4}$ & 56.4 & 56.4 & 78.7 & 67.5 & 73.2 & 58.2 & - & 40.7 & - & 52.6 & 39.5 & 30.6 & 28.7 & 29.7 \\
\hline 2 & $\mathrm{Ca}_{2} \mathrm{Al}_{2} \mathrm{SiO}_{7}$ & 35.0 & 35.0 & 18.7 & 26.8 & 25.4 & - & 53.6 & 16.1 & - & - & - & - & - & - \\
\hline $3 \mathrm{I}$ & $\mathrm{Ca}_{24} \mathrm{Al}_{28} \mathrm{O}_{65} \mathrm{~S}$ & - & - & - & - & - & 36.5 & 42.4 & 38.3 & - & 24.5 & 18.4 & 45.3 & 43.1 & 44.2 \\
\hline 3 II & $\mathrm{Ca}_{24} \mathrm{Al}_{28} \mathrm{O}_{64} \mathrm{~S}_{2}$ & - & - & - & - & - & - & - & - & 83.0 & - & 20.8 & - & - & - \\
\hline 4 & $\mathrm{Ca}_{2} \mathrm{SiO}_{4}$ & 8.6 & 8.6 & 2.6 & 5.6 & 1.4 & 5.3 & 4.0 & 4.9 & 17.0 & 22.8 & 21.3 & 24.1 & 28.1 & 26.1 \\
\hline \multicolumn{3}{|c|}{ Region area $(\%)$} & 50 & 50 & & & 70 & 30 & & 25 & 75 & & 50 & 50 & \\
\hline
\end{tabular}

\section{Electron Microprobe Analysis}

After the experiment, each crucible was cut axially along its diameter. Then, the cross-section was examined for a representative area using an optical microscope. Subsequently, that area was cut out for further examination. Each piece was cleaned, mounted, polished and carbon coated. In the microprobe, each phase in the sample was identified and its composition analysed. Also, the amount of the phases were determined through image analysis. Electron micrographs were taken of representative areas on the sample. If different areas could be identified on the sample, each of which had a different composition, each area was analyzed using the electron microprobe and labeled as a different region and an optical microscope was used to determine the relative amount of each region present in the sample to arrive at an overall composition. The electron microprobe used was the JEOL 733 SUPERPROBE. Wavelength-dispersive spectrometers (WDS) were used for the composition analysis. Synthetic anorthite $\left(\mathrm{CaAl}_{2} \mathrm{Si}_{2} \mathrm{O}_{8}\right)$ was used as a standard for $\mathrm{Ca}, \mathrm{Al}, \mathrm{Si}$, and $\mathrm{O}$, and iron sulphide $(\mathrm{FeS})$ for $\mathrm{S}$.

\section{Discussion}

\subsection{Crystallization Path and Incorporation of $\mathrm{CaS}$ in Optimized Secondary Steelmaking Slag}

The empirical formulae of the phases present in the slowly cooled samples experiments $\mathrm{A}-\mathrm{F}$ as analyzed with the electron microprobe are listed in the first column of
Table 2. The average normalized area of each phase present is listed for each experiment. When more than one region was present in one sample the results for each region are also listed, preceding the average analysis. The area of each region present, as this was identified with optical microscopy, is listed in the last line of Table 2. The results are also plotted in Fig. 3, where the average normalized area of each phase present for experiments $\mathrm{A}-\mathrm{F}$ is plotted. The analyses used gave a total of $100.0(1.5) \mathrm{wt} \%$ where the standard deviation to the last significant digit or digits is included inside the parenthesis. The oxygen was calculated through charge balance.

Phase 1 or monocalcium aluminate has, within the experimental errors, the stoichiometric composition suggested by the formula $\mathrm{CaAl}_{2} \mathrm{O}_{4}$ or $\mathrm{CA}$, as it is used in the cement chemistry nomenclature. Phase 2 or gehlenite is disordered with respect to the aluminum and silicon. Phase 4 or dicalcium silicate has aluminum present in small amounts. For phases 1, 2 and 4 the respective empirical formulas that were determined from the image analysis are $\mathrm{Ca}_{1.01(1)} \mathrm{Al}_{1.98(1)} \mathrm{Si}_{0.01} \mathrm{O}_{4.00}$, $\mathrm{Ca}_{2.18(2)} \mathrm{Al}_{2.52(4)} \mathrm{Si}_{0.45(1)} \mathrm{O}_{6.85(6)}$ and $\mathrm{Ca}_{1.97(3)} \mathrm{Al}_{0.10(4)^{-}}$ $\mathrm{Si}_{0.94(4)} \mathrm{O}_{3.99(7)}$, with an average total of $99.28(8)$, $100.60(57)$ and $98.96(68) \mathrm{wt} \%$, respectively. Phases 3I and 3II listed in Table 2 are sulfur containing phases. For phase 3I, the empirical formula is $\mathrm{Ca}_{23.87(7)} \mathrm{Al}_{28.04(8)^{-}}$ $\mathrm{Si}_{0.06(1)} \mathrm{S}_{1.06(2)} \mathrm{O}_{64.98}$, with an average total of $99.11 \mathrm{wt} \%$ and for phase 3II, the empirical formula is $\mathrm{Ca}_{21.27(6)^{-}}$ $\mathrm{Al}_{29.60(9)} \mathrm{Si}_{0.16(1)} \mathrm{S}_{2.02(3)} \mathrm{O}_{63.96}$, with an average total of 


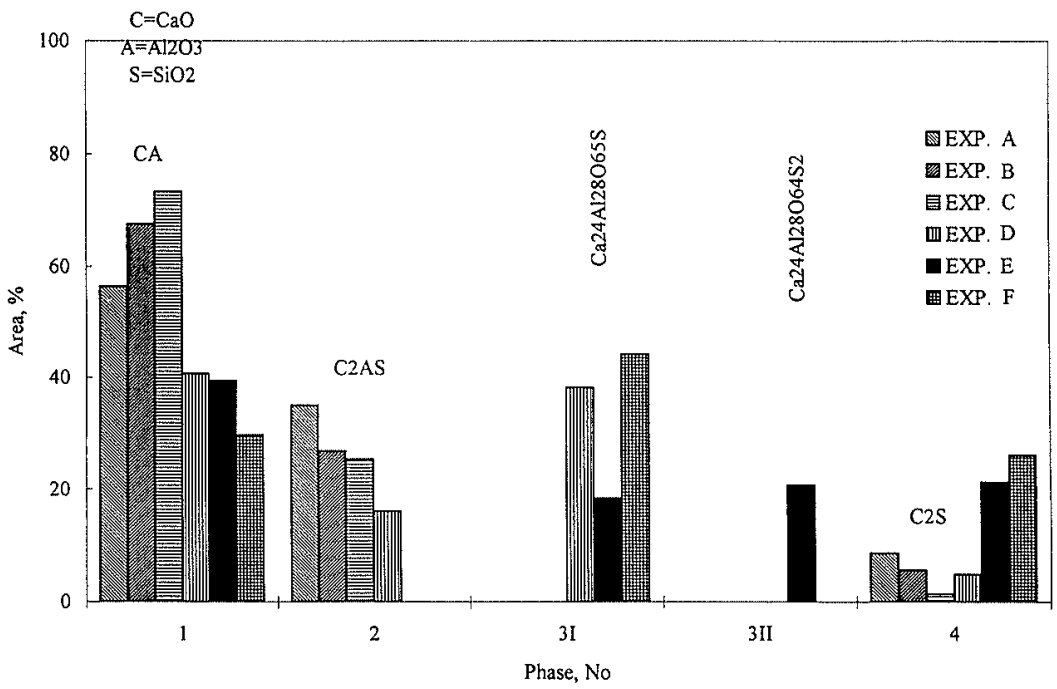

Fig. 3. Image analyses depicting the amounts of different phases present in slowly cooled optimized secondary steelmaking siag with CaS.

$99.79 \mathrm{wt} \%$.

Phases that were present in small amounts are not listed in Table 2 or plotted in Fig. 3. For instance, in experiment $\mathrm{F}$ another sulfur phase, that constituted less than $1 \%$ of the slag sample, is present with empirical formula $\mathrm{Ca}_{22.86(7)} \mathrm{Al}_{28.78(8)} \mathrm{Si}_{0.11(1)} \mathrm{S}_{3.12(4)} \mathrm{O}_{63.14}$, with an average total of $100.88 \mathrm{wt} \%$.

Based on the electron microprobe results, i.e., the quantitative and image analysis of each phase present, the average composition of the slowly cooled melt of $\mathrm{CaO}-\mathrm{Al}_{2} \mathrm{O}_{3}-\mathrm{SiO}_{2}-\mathrm{CaS}$ in experiments $\mathrm{A}-\mathrm{F}$ was calculated. The results are listed in Table 3. It may also be noted from Table 3 that due to alumina dissolution from the crucible, the composition of the starting slag changed.

Based on the information obtained from the differential thermal analysis and the electron microprobe results, the sequence of crystallization and incorporation of sulfur was determined for experiments $A-F$. Experiments $\mathrm{A}-\mathrm{C}$, wherein no sulfur was present, refer to the ternary $\mathrm{CaO}-\mathrm{Al}_{2} \mathrm{O}_{3}-\mathrm{SiO}_{2}$ which is very well established. In experiments $\mathrm{D}-\mathrm{F}$ though, the sulfur phases belong to the ternary system $\mathrm{CaO}-\mathrm{Al}_{2} \mathrm{O}_{3}-\mathrm{CaS}$, and these are phases $3 \mathrm{I}$ and 3II. Since these phases form first at $1349( \pm 21) \mathrm{K}$ (as it is shown later in this section) and remain solid, the liquid left must be a part of the ternary $\mathrm{CaO}-\mathrm{Al}_{2} \mathrm{O}_{3}-\mathrm{SiO}_{2}$. From that point on, the cooling path could be predicted using the lever rule from the well known ternary phase diagram. The phases that crystallized as well as the amounts and the transformation temperatures could be predicted.

The results of the calculation are shown in Table $\mathbf{4}$ for experiments $\mathrm{A}-\mathrm{F}$ and the corresponding transformation temperatures in the ternary $\mathrm{CaO}-\mathrm{Al}_{2} \mathrm{O}_{3}-\mathrm{SiO}_{2}$ phase diagram are listed in Table 5.

The good agreement of the predicted total amount of each phase that crystallized during cooling (Table 4) and the one calculated through image analysis (Table 3) should be noted. For example, in Table 4 for experiment $\mathrm{E}$, the initial slag composition was iteratively determined to be $x_{i}^{o}$. This is very close to the as measured starting
Table 3. Composition of Phases $1-4$ as analyzed in the electron microprobe, area of each phase from image analysis and average composition (experiments A-F).

Normalized composition, wt $\%$ - Electron microprode Compound Phase 1 Phase 2 Phase 31 Phase 3II Phase 4

\begin{tabular}{|c|c|c|c|c|c|c|}
\hline $\mathrm{CaO}$ & 35.48 & 40.90 & \multicolumn{2}{|c|}{48.25} & 42.99 & 65.12 \\
\hline $\mathrm{Al}_{2} \mathrm{O}_{3}$ & 64.52 & 37.18 & \multicolumn{2}{|c|}{51.17} & 55.83 & 0.00 \\
\hline $\mathrm{SiO}_{2}$ & 0.00 & 21.91 & \multicolumn{2}{|c|}{0.00} & 0.00 & 34.88 \\
\hline$S^{2}$ & 0.00 & 0.00 & \multicolumn{2}{|c|}{1.15} & 2.34 & 0.00 \\
\hline Total & 100.00 & 100.00 & \multicolumn{2}{|c|}{100.57} & 101.17 & 100.00 \\
\hline$-\mathrm{O}=\mathrm{S}$ & - & - & \multicolumn{2}{|c|}{0.57} & 1.17 & - \\
\hline Total & 100.00 & 100.00 & \multicolumn{2}{|c|}{100.00} & 100.00 & 100.00 \\
\hline \multicolumn{7}{|c|}{ Normalized area $(\%)$} \\
\hline Exp. A & 56.4 & 35.0 & \multicolumn{2}{|c|}{-} & - & 8.6 \\
\hline Exp. B & 67.5 & 26.8 & \multicolumn{2}{|c|}{ - } & - & 5.6 \\
\hline Exp. C & 73.2 & 25.4 & \multicolumn{2}{|c|}{-} & - & 1.4 \\
\hline Exp. D & 40.7 & 16.1 & \multicolumn{2}{|c|}{38.3} & - & 4.9 \\
\hline Exp. E & 39.5 & - & \multicolumn{2}{|c|}{18.4} & 20.8 & 21.3 \\
\hline Exp. $F$ & 29.7 & - & \multicolumn{2}{|c|}{44.2} & - & 26.1 \\
\hline \multicolumn{7}{|c|}{ Average normalized composition ( $\mathrm{wt} \%$ ) } \\
\hline Compound & Exp. A & Exp. B & Exp. C & Exp. D & Exp. E & Exp. F \\
\hline $\mathrm{CaO}$ & 39.9 & 38.6 & 37.3 & 42.6 & 45.6 & 48.7 \\
\hline $\mathrm{Al}_{2} \mathrm{O}_{3}$ & 49.4 & 53.5 & 56.7 & 51.7 & 46.3 & 41.6 \\
\hline $\mathrm{SiO}_{2}$ & 10.7 & 7.8 & 6.0 & 5.2 & 7.4 & 9.1 \\
\hline $\mathrm{s}$ & 0.0 & 0.0 & 0.0 & 0.4 & 0.7 & 0.5 \\
\hline Total & 100.0 & 100.0 & 100.0 & 100.0 & 100.0 & 100.0 \\
\hline$-\mathrm{O}=\mathrm{S}$ & 0.0 & 0.0 & 0.0 & 0.1 & 0.2 & 0.1 \\
\hline Total & 100.0 & 100.0 & 100.0 & 97.9 & 99.8 & 99.9 \\
\hline
\end{tabular}

average slag composition reported in Table 3 . Assuming $x_{i}^{o}$ as the starting slag composition, the combined sulfur phases, $w^{3}=46.5 \%$ of the initial slag in the form of the ternary phases, designated as phases 3I and 3II, with average overall composition $x_{i}^{3}$, crystallize first and the 
Table 4. Crystallization path for experiments A-F. Nomenclature

- Compounds: $C \equiv \mathrm{CaO}, A \equiv \mathrm{Al}_{2} \mathrm{O}_{3}, S i \equiv \mathrm{SiO}_{2}, S \equiv \mathrm{S}$

$p=1,2,3,4$, where $\mathrm{CaAl}_{2} \mathrm{O}_{4} \equiv 1, \mathrm{Ca}_{2} \mathrm{Al}_{2} \mathrm{SiO}_{7} \equiv 2, \mathrm{Ca}_{24} \mathrm{Al}_{28} \mathrm{O}_{64-65} \mathrm{~S}_{1-2} \equiv 3(\mathrm{I} / \mathrm{II}), \mathrm{Ca}_{2} \mathrm{SiO}_{4} \equiv 4$

- $o \equiv$ initial liquid,

$l_{k} \equiv$ liquid left after precipitation, $k=1,2,3, \cdots$,

$l_{k(k+1)} \equiv$ liquid solidified from $l_{k}$ to $l_{k+1}$

$s \equiv$ solid

- Composiion in wt \%: $x_{i}^{j}, x_{i}^{p}, i=C, A, S i, S$ and $j=0, l_{1}, l_{2}, l_{3}, s$

- Weight $\%: w_{k_{(k+1)}^{j}}^{j}, w_{s}^{j}, w^{p}, j \neq 0$.

\begin{tabular}{|c|c|c|c|c|c|c|c|c|}
\hline & $x_{i}^{0}$ & $x_{i}^{l_{1}}$ & $x_{i}^{I_{i}}$ & $x_{i}^{l_{i}}=x_{i}^{s}$ & $x_{i}^{3}$ & $x_{i}^{1}$ & $x_{i}^{2}$ & $x_{i}^{4}$ \\
\hline$C$ & 39.0 & 39.0 & 48.3 & 48.3 & 48.3 & 35.5 & 40.9 & 65.1 \\
\hline$A$ & 51.4 & 51.4 & 42.0 & 42.0 & 51.2 & 64.5 & 37.2 & 0.0 \\
\hline$S i$ & 9.6 & 9.6 & 9.7 & 9.7 & 0.0 & 0.0 & 21.9 & 34.9 \\
\hline$S$ & 0.0 & 0.0 & 0.0 & 0.0 & 1.2 & 0.0 & 0.0 & 0.0 \\
\hline$w^{j}$ & 100.0 & 100.0 & 11.7 & 11.7 & & & & \\
\hline$w^{3}$ & & & & & 0.0 & 0.0 & 0.0 & 0.0 \\
\hline$w_{l_{2}}^{j}$ & & & & & 0.0 & 0.0 & 0.0 & 0.0 \\
\hline$w_{l_{2}}^{j}$ & & & & & 0.0 & 49.6 & 38.6 & 0.0 \\
\hline$w_{s}^{j}$ & & & & & 0.0 & 10.0 & -4.1 & 5.9 \\
\hline$w^{p}$ & & & & & 0.0 & 59.6 & 34.5 & 5.9 \\
\hline
\end{tabular}

\begin{tabular}{|c|c|c|c|c|c|c|c|c|}
\hline & $x_{i}^{0}$ & $x_{i}^{\prime}$ & $x_{i}^{\prime}$ & $x_{i}^{\prime}=x_{i}^{s}$ & $x_{i}^{3}$ & $x_{i}^{1}$ & $x_{i}^{2}$ & $x_{i}^{4}$ \\
\hline$C$ & 38.6 & 39.3 & 48.3 & 48.3 & 48.3 & 35.5 & 40.9 & 65.1 \\
\hline$A$ & 53.5 & 51.1 & 42.0 & 42.0 & 51.2 & 64.5 & 37.2 & 0.0 \\
\hline$S i$ & 7.8 & 9.6 & 9.7 & 9.7 & 0.0 & 0.0 & 21.9 & 34.9 \\
\hline$S$ & 0.0 & 0.0 & 0.0 & 0.0 & 1.2 & 0.0 & 0.0 & 0.0 \\
\hline$w^{J}$ & 100.0 & 82.3 & 11.6 & 11.6 & & & & \\
\hline$w^{3}$ & & & & & 0.0 & 0.0 & 0.0 & 0.0 \\
\hline$w_{l_{1}}^{j}$ & & & & & 0.0 & 17.7 & 0.0 & 0.0 \\
\hline$w_{l_{12}}^{j}$ & & & & & 0.0 & 39.7 & 30.9 & 0.0 \\
\hline$w_{s}^{j}$ & & & & & 0.0 & 9.9 & -4.1 & 5.8 \\
\hline$w^{p}$ & & & & & 0.0 & 67.4 & 26.8 & 5.8 \\
\hline
\end{tabular}

\begin{tabular}{|c|c|c|c|c|c|c|c|c|}
\hline & $x_{i}^{o}$ & $x_{i}^{l_{i}}$ & $x_{i}^{l_{2}^{\prime}}$ & $x_{i}^{l_{s}}=x_{i}^{s}$ & $x_{i}^{3}$ & $x_{i}^{1}$ & $x_{i}^{2}$ & $x_{i}^{4}$ \\
\hline$C$ & 37.2 & 38.3 & 48.3 & 48.3 & 48.3 & 35.5 & 40.9 & 65.1 \\
\hline$A$ & 56.7 & 52.1 & 42.0 & 42.0 & 51.2 & 64.5 & 37.2 & 0.0 \\
\hline$S i$ & 6.1 & 9.6 & 9.7 & 9.7 & 0.0 & 0.0 & 21.9 & 34.9 \\
\hline$S$ & 0.0 & 0.0 & 0.0 & 0.0 & 1.2 & 0.0 & 0.0 & 0.0 \\
\hline$w^{j}$ & 100.0 & 63.0 & 2.8 & 2.8 & & & & \\
\hline$w^{3}$ & & & & & 0.0 & 0.0 & 0.0 & 0.0 \\
\hline$w_{l_{1}}^{j}$ & & & & & 0.0 & 37.0 & 0.0 & 0.0 \\
\hline$w_{l_{y}}^{j}$ & & & & & 0.0 & 33.8 & 26.4 & 0.0 \\
\hline$w_{s}^{j}$ & & & & & 0.0 & 2.4 & -1.0 & 1.4 \\
\hline$w^{p}$ & & & & & 0.0 & 73.2 & 25.4 & 1.4 \\
\hline
\end{tabular}

\begin{tabular}{|c|c|c|c|c|c|c|c|c|}
\hline & $x_{i}^{o}$ & $x_{i}^{l_{i}}$ & $x_{i}^{l_{3}}$ & $x_{i}^{l^{\prime}}=x_{i}^{s}$ & $x_{i}^{3}$ & $x_{i}^{1}$ & $x_{i}^{2}$ & $x_{i}^{4}$ \\
\hline$C$ & 42.7 & 39.2 & 39.7 & 48.3 & 48.3 & 35.5 & 40.9 & 65.1 \\
\hline$A$ & 51.9 & 52.3 & 50.7 & 42.0 & 51.2 & 64.5 & 37.2 & 0.0 \\
\hline$S i$ & 5.0 & 8.1 & 9.6 & 9.7 & 0.0 & 0.0 & 21.9 & 34.9 \\
\hline$S$ & 0.4 & 0.0 & 0.0 & 0.0 & 1.2 & 0.0 & 0.0 & 0.0 \\
\hline$w^{j}$ & 100.0 & 61.7 & 54.5 & 9.8 & & & & \\
\hline$w^{3}$ & & & & & 38.3 & 0.0 & 0.0 & 0.0 \\
\hline$w_{l_{13}}^{j}$ & & & & & 0.0 & 7.2 & 0.0 & 0.0 \\
\hline$w_{l_{13}}^{j}$ & & & & & 0.0 & 25.2 & 19.6 & 0.0 \\
\hline$w_{s}^{j}$ & & & & & 0.0 & 8.4 & -3.5 & 4.9 \\
\hline \hline$w^{p}$ & & & & & 38.3 & 40.7 & 16.1 & 4.9 \\
\hline
\end{tabular}

\begin{tabular}{|c|c|c|c|c|c|c|c|c|}
\hline & $x_{i}^{o}$ & $x_{i}^{i_{i}}$ & $x_{i}^{l_{2}}$ & $x_{i}^{l_{j}}=x_{i}^{s}$ & $x_{i}^{3}$ & $x_{i}^{1}$ & $x_{i}^{2}$ & $x_{i}^{4}$ \\
\hline$C$ & 45.7 & 46.3 & 48.2 & 48.3 & 45.1 & 35.5 & 40.9 & 65.1 \\
\hline$A$ & 46.6 & 40.9 & 42.2 & 42.0 & 53.2 & 64.5 & 37.2 & 0.0 \\
\hline$S i$ & 6.8 & 12.8 & 9.6 & 9.7 & 0.0 & 0.0 & 21.9 & 34.9 \\
\hline$S$ & 0.8 & 0.0 & 0.0 & 0.0 & 1.8 & 0.0 & 0.0 & 0.0 \\
\hline$w^{j}$ & 100.0 & 53.5 & 39.7 & 39.2 & & & & \\
\hline$w^{3}$ & & & & & 46.5 & 0.0 & 0.0 & 0.0 \\
\hline$w_{l_{i s}^{j}}^{j}$ & & & & & 0.0 & 0.0 & 13.9 & 0.0 \\
\hline$w_{l_{s}}^{j}$ & & & & & 0.0 & 0.0 & 0.0 & 0.0 \\
\hline$w_{s}^{j}$ & & & & & 0.0 & 33.5 & -13.9 & 19.6 \\
\hline$w^{p}$ & & & & & 46.5 & 33.5 & 0.0 & 19.6 \\
\hline
\end{tabular}

\begin{tabular}{|c||c|c|c|c|c|c|c|c|}
\hline & $x_{i}^{0}$ & $x_{i}^{l_{i}^{\prime}}$ & $x_{i}^{l_{i}}$ & $x_{i}^{l_{i}}=x_{i}^{s}$ & $x_{i}^{3}$ & $x_{i}^{1}$ & $x_{i}^{2}$ & $x_{i}^{4}$ \\
\hline$C$ & 49.0 & 49.7 & 49.6 & 48.3 & 48.3 & 35.5 & 40.9 & 65.1 \\
\hline$A$ & 41.7 & 34.1 & 33.8 & 42.0 & 51.2 & 64.5 & 37.2 & 0.0 \\
\hline$S i$ & 9.2 & 16.4 & 16.6 & 9.7 & 0.0 & 0.0 & 21.9 & 34.9 \\
\hline$S$ & 0.5 & 0.0 & 0.0 & 0.0 & 1.2 & 0.0 & 0.0 & 0.0 \\
\hline$w^{j}$ & 100.0 & 55.8 & 55.6 & 34.2 & & & & \\
\hline$w^{3}$ & & & & & 44.2 & 0.0 & 0.0 & 0.0 \\
\hline$w_{l_{1}}^{j}$ & & & & & 0.0 & 0.0 & 0.0 & 0.0 \\
\hline$w_{l_{2}}^{j}$ & & & & & 0.0 & 0.0 & 12 & 9.5 \\
\hline$w_{s}^{j}$ & & & & & 0.0 & 29.2 & 12 & 17.1 \\
\hline \hline$w^{P}$ & & & & & 44.2 & 29.2 & 0 & 26.6 \\
\hline
\end{tabular}

Table 5. Transformation temperatures for slowly cooled optimized secondary steelmaking slag with CaS.

\begin{tabular}{cccc}
\hline Experiment & \multicolumn{3}{c}{$T(\mathrm{~K})$} \\
& 1st & 2nd & 3rd \\
\hline A & 1785 & 1785 & 1653 \\
B & 1798 & 1785 & 1653 \\
C & 1802 & 1785 & 1653 \\
D & 1793 & 1785 & 1653 \\
E & 1763 & 1653 & 1653 \\
F & 1773 & 1773 & 1653 \\
\hline
\end{tabular}

remaining slag with weight $w^{l_{1}}=53.5 \%$ of the initial slag and composition $x_{i}^{l_{1}}$ cools until approximately $1763 \mathrm{~K}$ is reached. Phase 2 with composition $x_{i}^{2}$ starts to crystallize at $1763 \mathrm{~K}$. At $1653 \mathrm{~K}, 13.9 \%$ of phase $2\left(w_{l_{12}}^{2}\right)$ crystallizes. From the remaining liquid with composition $x_{i}^{l_{3}}=x_{i}^{s}, 33.5 \%$ of phase $1\left(w_{s}^{1}\right)$ and $19.6 \%$ of phase 4 $\left(w_{s}^{4}\right)$ crystallize while $13.9 \%$ of phase $2\left(w_{s}^{2}\right)$ dissolves. The resulting predicted weights of phase $1-4$ present after the whole liquid transformed to solid are $w^{1}=33.5 \%$, $w^{2}=0.0 \%, w^{3}=46.5 \%$ and $w^{4}=19.6 \%$, respectively, which can be compared with results of the image analysis 
for experiment $\mathrm{E}$ in Table 3: $A^{1}=39.5 \%$ (phase 1), $A^{2}=0.0 \% \quad$ (phase 2), $A^{3}=39.2 \% \quad$ (phase 3) and $A^{4}=21.3 \%$ (phase 4 ); the results agree to within $15 \%$. In the same way, the analyzed and the predicted results for the rest of the experiments $A-D$ and $F$ can be compared from Tables 3 and 4 , respectively, and the agreement seems to be better than that discussed for $\mathrm{E}$.

From Table 2, for experiments $\mathrm{D}-\mathrm{F}$ it is clear that phases 3I and 3II with near stoichiometric formulas $\mathrm{Ca}_{24} \mathrm{Al}_{28} \mathrm{O}_{65} \mathrm{~S}$ and $\mathrm{Ca}_{24} \mathrm{Al}_{28} \mathrm{O}_{64} \mathrm{~S}_{2}$ are the two phases that incorporated sulfur in their structure.

As the mixtures of the optimized secondary steelmaking master slag with $\mathrm{CaS}$ were heated at $1 / 3 \mathrm{~K} \mathrm{~s}^{-1}$, several peaks could be detected in the thermograms generated in the present work. At 803(59) $\mathrm{K}$ the decomposition ${ }^{7)}$ of $\mathrm{Ca}(\mathrm{OH})_{2}(788-863 \mathrm{~K})$ gives an endothermic peak. At $1175(42) \mathrm{K}$ an endothermic peak indicates the onset of dehydration $^{8)}$ of $\mathrm{C}_{11} \mathrm{~A}_{7} \cdot \mathrm{Ca}(\mathrm{OH})_{2}(1173 \mathrm{~K})$, closely followed by an exothermic peak at $1349(21) \mathrm{K}$ related to the incorporation of $S$ in the structure of $C_{11} A_{7}$. $\mathrm{Ca}(\mathrm{OH})_{2}$, giving $\mathrm{C}_{11} \mathrm{~A}_{7} \cdot \mathrm{CaS}$ (and $\mathrm{C}_{10} \mathrm{~A}_{7} \cdot 2 \mathrm{CaS}$ in experiment $\mathrm{E})$. The polymorphic transition ${ }^{9)} \gamma \rightarrow \alpha$ of $12 \mathrm{CaO} \cdot 7 \mathrm{Al}_{2} \mathrm{O}_{3}$ can be assigned to the endothermic peak at $1487(25) \mathrm{K}$. Finally above this temperature, the endothermic peak is related to the melting of the remaining material.

In the subsequent cooling and heating cycles $(1 / 30-$ $1 / 12 \mathrm{~K} \mathrm{~s}^{-1}$ ) the system is homogenized and in the final cooling $\left(1 / 3 \mathrm{~K} \mathrm{~s}^{-1}\right)$ the phases identified in the present study were crystallized. In Fig. $4(\times 1000)$, taken in the electron microprobe for the sample from experiment $\mathrm{E}$ the matrix is phase 3II $\left(\mathrm{Ca}_{24} \mathrm{Al}_{28} \mathrm{O}_{64} \mathrm{~S}_{2}\right)$ and the light crystals, $2 \times 2 \mu \mathrm{m}$ in size, are phase $4\left(\beta-\mathrm{Ca}_{2} \mathrm{SiO}_{4}\right)$. In Fig. $5(\times 1000)$, for the same experiment $\mathrm{E}$, the matrix is phase $1\left(\mathrm{CaAl}_{2} \mathrm{O}_{4}\right)$, the light crystals $5 \times 5 \mu \mathrm{m}$ in size, are phase $4\left(\mathrm{Ca}_{2} \mathrm{SiO}_{4}\right)$ and the dark crystals, $20 \times 20 \mu \mathrm{m}$ in size, are phase $3 \mathrm{I}\left(\mathrm{Ca}_{24} \mathrm{Al}_{28} \mathrm{O}_{65} \mathrm{~S}\right)$.

\subsection{Incorporation of CaS in a Typical Ironmaking and Steelmaking Slag}

The empirical formulae of the phases present in the samples as analyzed with the electron microprobe, are listed in the first column of Table 6 . The phases identified

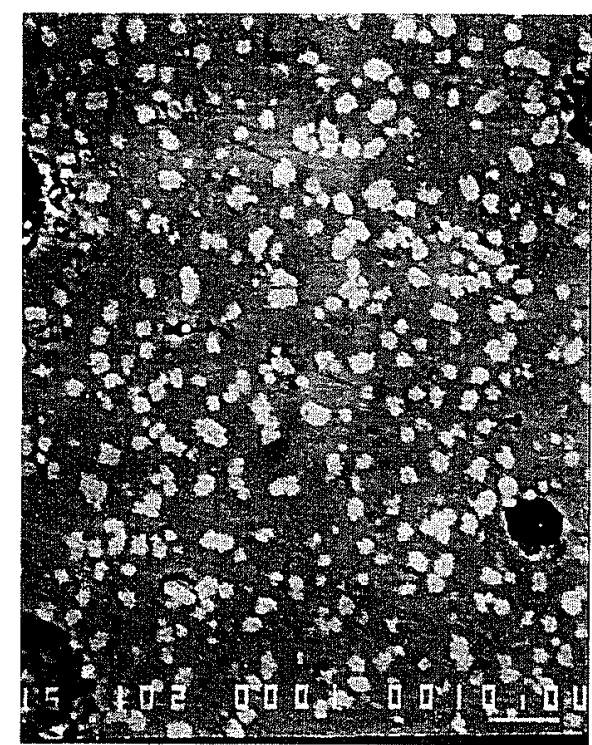

Fig. 4. An electron microprobe micrograph of the slowly cooled slag in experiment $\mathrm{E}$. Gray matrix: $22 \mathrm{CaO}$ $14 \mathrm{Al}_{2} \mathrm{O}_{3} \cdot 2 \mathrm{CaS}$; Light crystals: $2 \mathrm{CaO} \cdot \mathrm{SiO}_{2}$.

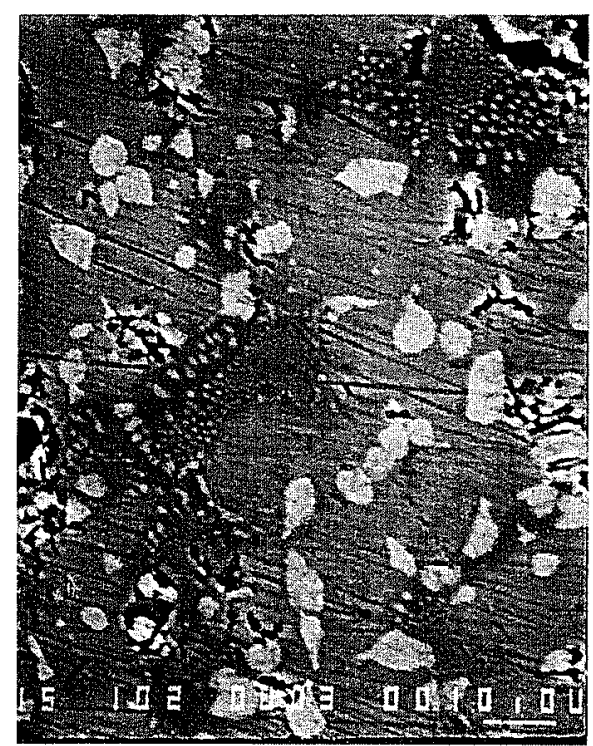

Fig. 5. An electron microprobe micrograph of the slowly cooled slag in experiment $\mathrm{E}$. Gray matrix: $\mathrm{CaO} \cdot \mathrm{Al}_{2} \mathrm{O}_{3}$; Light crystals: $2 \mathrm{CaO} \cdot \mathrm{SiO}_{2}$; Dark crystals: $23 \mathrm{CaO}$ $14 \mathrm{Al}_{2} \mathrm{O}_{3} \cdot \mathrm{CaS}$

Table 6. Electron Microprobe image analysis of the ironmaking and steelmaking slag with CaS

\begin{tabular}{|c|c|c|c|c|c|c|c|c|c|c|c|c|c|c|c|c|}
\hline & Phase & G & & & $\mathrm{H}$ & & & I & & & & & $\mathrm{J}$ & & & $\mathrm{K}$ \\
\hline 5 & $\mathrm{Ca}_{1.5} \mathrm{Al}_{1,4} \mathrm{Si}_{2.2} \mathrm{O}_{7.9}$ & 34.7 & - & - & - & - & - & - & - & - & - & - & - & - & - & - \\
\hline 2 & $\mathrm{Ca}_{2} \mathrm{Al}_{2} \mathrm{SiO}_{7}$ & 65.3 & - & - & - & - & - & - & - & - & - & - & - & - & - & - \\
\hline $2 \mathrm{I}$ & $\mathrm{Ca}_{2.4} \mathrm{Al}_{0.7} \mathrm{Si}_{1.8} \mathrm{~S}_{0.1} \mathrm{O}_{7.0}$ & - & 100.0 & - & 60.0 & - & - & - & - & 82.3 & 100.0 & - & 61.0 & - & - & - \\
\hline $2 I I$ & $\mathrm{Ca}_{2.1} \mathrm{Al}_{0.9} \mathrm{Si}_{1.8} \mathrm{O}_{7.1}$ & - & - & 77.5 & 31.0 & - & - & - & - & - & - & - & - & - & - & - \\
\hline $2 I I I$ & $\mathrm{Ca}_{1.9} \mathrm{Al}_{1.4} \mathrm{Si}_{1.6} \mathrm{O}_{7.1}$ & - & - & - & - & 64.8 & 55.6 & 61.1 & - & - & - & - & - & - & - & - \\
\hline $2 \mathrm{IV}$ & $\mathrm{Ca}_{2.1} \mathrm{Al}_{1.0} \mathrm{Si}_{1.8} \mathrm{~S}_{0.2} \mathrm{O}_{7.0}$ & - & - & - & - & - & 27.3 & 10.9 & 76.1 & - & - & - & 2.3 & - & - & - \\
\hline $2 \mathrm{VI}$ & $\mathrm{Ca}_{2.0} \mathrm{Al}_{1.2} \mathrm{Si}_{1.7} \mathrm{~S}_{0.1} \mathrm{O}_{7.1}$ & - & - & - & - & - & - & - & - & - & - & 71.4 & 17.9 & 6.7 & - & 3.3 \\
\hline 2VII & $\mathrm{Ca}_{1.9} \mathrm{Al}_{1.7} \mathrm{Si}_{1.4} \mathrm{O}_{7.1}$ & - & - & - & - & - & - & - & - & - & - & - & - & 65.3 & - & 32.6 \\
\hline 2VIII & $\mathrm{Ca}_{1,9} \mathrm{Al}_{1,9} \mathrm{Si}_{1.2} \mathrm{O}_{7,1}$ & - & - & - & - & - & - & - & - & - & - & - & - & - & 14.1 & 7.1 \\
\hline 6 & $\mathrm{CaSiO}_{3}$ & - & - & - & - & - & - & -- & - & - & - & - & - & 0.3 & 46.7 & 23.5 \\
\hline $6 I$ & $\mathrm{Ca}_{1.0} \mathrm{Al}_{0.1} \mathrm{Si}_{0.9} \mathrm{~S}_{0.1} \mathrm{O}_{2.9}$ & - & - & - & - & 10.8 & - & 6.5 & - & - & - & - & - & - & -- & - \\
\hline $6 \mathrm{II}$ & $\mathrm{Ca}_{1.1} \mathrm{Si}_{0.9} \mathrm{~S}_{0.2} \mathrm{O}_{2.8}$ & - & - & - & - & 10.8 & - & 6.5 & - & - & - & - & - & 0.3 & - & 0.1 \\
\hline 6111 & $\mathrm{Ca}_{0.9} \mathrm{Si}_{0.3} \mathrm{~S}_{0.8} \mathrm{O}_{3.0}$ & - & - & - & - & - & - & - & - & - & $\longrightarrow$ & - & - & - & 23.0 & 11.5 \\
\hline 4 & $\mathrm{Ca}_{2} \mathrm{SiO}_{4}$ & - & - & 22.5 & 9.0 & 13.6 & 17.2 & 15.1 & 23.9 & 17.7 & - & 28.6 & 18.8 & 27.5 & 16.3 & 21.9 \\
\hline & Region area $(\%)$ & & 60 & 40 & & 60 & 40 & & 3 & 62 & 10 & 25 & & 50 & 50 & \\
\hline
\end{tabular}


in the slowly cooled high silica experiments with and without the addition of $\mathrm{CaS}$ were all glass. The phases can be classified into four categories-phases 2, 4, 5 and 6. Phase 2 is gehlenite like and the average empirical formulae is $\mathrm{Ca}_{1.95(1)} \mathrm{Al}_{2.04(16)} \mathrm{Si}_{1.00(2)} \mathrm{O}_{7.01}$, with an average total of $101.20 \mathrm{wt} \%$. Phase 4 is very close to dicalcium silicate, average empirical formulae being $\mathrm{Ca}_{2.00(3)} \mathrm{Si}_{0.99(2)} \mathrm{O}_{4.00(6)}$, with an average total of 98.46(1.34) $\mathrm{wt} \%$. Phase 5 has an average empirical formulae $\mathrm{Ca}_{1.54(2)} \mathrm{Al}_{1.39(17)} \mathrm{Si}_{2.15(1)} \mathrm{O}_{7.93}$, with an average total of $100.68(2.84) \mathrm{wt} \%$. Phase 6 is monocalcium silicate like and has an average empirical formulae $\mathrm{Ca}_{0.98} \mathrm{Al}_{0.05} \mathrm{Si}_{0.97} \mathrm{~S}_{0.01} \mathrm{O}_{2.99}$, with an average total of $99.10 \mathrm{wt} \%$.

Since all the phases present are glasses, the analysis utilized for the prediction of the crystallization path in the optimized secondary steelmaking slag experiments is not applicable in this case.

As the mixtures of the ironmaking and steelmaking master slag with $\mathrm{CaS}$ were heated at $1 / 3 \mathrm{Ks}^{-1}$, an endothermic peak at $1574(9) \mathrm{K}$ is related to the melting process. In the subsequent cooling and heating cycles $\left(1 / 30-1 / 12 \mathrm{~K} \mathrm{~s}^{-1}\right)$ the system is homogenized and in the final cooling $\left(1 / 3 \mathrm{~K} \mathrm{~s}^{-1}\right)$ the phases identified in the present study were solidified.

In experiment $G$ no calcium sulfide was added. For this experiment no transformation or reaction temperature could be determined, since no deflection of the thermocouple inside the slag was recorded. In explaining the reason why this has happened, a simplified model for glass formation by Uhlmann and Onorato ${ }^{10)}$ was employed. This model describes the critical cooling rates implied by the occurrence of glassy or partially crystalline bodies. It is based on the formal theory of transformation kinetics, combined with a relation between the temperature of the nose of a TTT curve and the liquidus temperature. Also used is a relation between the barrier to crystal nucleation and the entorpy of fusion and a Vogel-Fulcher description of liquid viscosity using the glass transition temperature as a corresponding states parameter. Application of the simplified model to a number of lunar samples indicates agreement within about an order of magnitude.

The critical cooling rate for glass formation is ${ }^{10}$ )

$$
\begin{aligned}
& \left(\frac{d T}{d t}\right)_{\text {crit }}= \\
& \frac{A T_{E}^{2}}{\eta\left(0.77 T_{E}\right)} \exp (-0.2117 B)\left[1-\exp \left(-\frac{0.3 \Delta H_{M}}{R T_{E}}\right)\right]^{3 / 4}
\end{aligned}
$$

where $\eta$ is the viscosity, in $\mathrm{Pa} \cdot \mathrm{s} ; T_{E}$ is the melting point or liquidus temprature, in $\mathrm{K}$; the barrier to crystal nucleation is $B k T$ at a relative undercooling $\left(\Delta T / T_{E}\right)$ of $0.2 ; \Delta H_{M}$ is the molar heat of fusion in $\mathrm{J} \mathrm{mol}^{-1}$; and $A \cong 4 \times 10^{-6} \mathrm{~J} \mathrm{~m}^{-3} \mathrm{~K}^{-1}$. On this basis, the prediction of the critical cooling rate requires only the viscosity at a single temperature $\left(0.77 T_{E}\right)$, the heat of fusion and the barrier to crystal nucleation. From available data on nucleation behavior for a wide variety of materials at a relative undercooling $\left(\Delta T / T_{E}\right)$ of 0.2 , the results indicate a typical nucleation barrier of about $12.6\left(\left(\Delta S_{M} / R\right) k T\right)$. Then the barrier to crystal nucleation $B \approx 12.6\left(\Delta S_{M} / R\right)$, where $\Delta S_{M}$ is the molar entropy of fusion.

From the phase diagram ${ }^{11)}$ of $\mathrm{CaO}-\mathrm{Al}_{2} \mathrm{O}_{3}-\mathrm{SiO}_{2}$ the liquidus temperature of $\mathrm{CaO} \cdot \mathrm{SiO}_{2}$ is $T_{E}=1817 \mathrm{~K}$. The molar heat and entropy of fusion are given by ${ }^{12)}$ $\Delta H_{M}=82.8 \mathrm{~kJ} \mathrm{~mol}^{-1}$ and $\Delta S_{M}=45.55 \mathrm{~J} \mathrm{~mol}^{-1} \mathrm{~K}^{-1}$, respectively. The viscosity at $0.77 T_{E}=1399 \mathrm{~K}$ is given as $\approx 10^{3} \mathrm{~Pa} \cdot \mathrm{s} .{ }^{13)}$ Substituting and solving for the critical cooling rate for glass formation a value of $\approx 5 \times 10^{-9} \mathrm{~K}$ $\mathrm{s}^{-1}$ is calculated. Thus, for the high silica slag without the addition of $\mathrm{CaS}$, it is practically impossible to determine the transformation or the reaction temperatures, since a very low cooling rate of that order is difficult under the current experimental conditions. However, when $\mathrm{CaS}$ was added to the slag it was possible to measure some of the transformation or reaction temperatures. This was probably due to the fact that $\Delta S_{M}$ decreased (as evidenced by the formation of numerous phases) and thereby increased the critical cooling rate of the system.

From Eq. (1) for smaller $\Delta S_{M}$ the exponential term $(\exp (-0.2117 B))$ will become significantly larger and the critical cooling rate needed will also correspondingly become significantly larger. For the optimized secondary steelmaking slags the transformation temperatures were detected easily. The fact that a slag high in silica will have a high $\Delta S_{M}$ or that a slag low in silica will have a low $\Delta S_{M}$ explains our experimental observations. Of course, in addition, a slag high in silica will be more viscous than the optimized secondary steelmaking slag and thus it will also decrease the critical cooling rate.

\section{Conclusions}

The optimized secondary steelmaking synthetic slag needs to find practical applications. It could either be used as a product by itself or as a reservoir of hazardous elements, like chlorine and sulfur, and subsequently be used as a source material for other industries. It is shown that the optimized secondary ladle steelmaking slags can incorporate chlorine and sulfur in their structure in the form of phases based on the crystal structure of the mayenite. The recovery of sulfur can reach up to $100 \%$. Based on the information obtained from DTA and EMP the sequence of crystallization and incorporation of sulfur was determined. The phases that crystallized as well as the amounts and the transformation temperatures could be predicted and these agreed well with DTA and EMP. The sulfur phase crystallized first and remained solid throughout the experiment. The composition of the system on the ternary $\mathrm{CaO}-\mathrm{Al}_{2} \mathrm{O}_{3}-\mathrm{SiO}_{2}$ was located after the sulfur phases crystallized and then the lever rule was applied on the ternary to determine the crystallization path and the amounts of other phases. For comparison, typical ironmaking and steelmaking slags were also utilized to study the incorporation of sulfur in their structure. The resulting phases were all glasses. The mechanism of sulfur incorporation in these slags is not yet clear. For the typical ironmaking and steelmaking slag, the determination of the transformation tempera- 
tures was not possible during heating and cooling of the melt. The addition of $\mathrm{CaS}$ enabled us to determine some of the transformation temperatures. This observation was theoreitcally rationalized.

On the basis of the conclusions of this work, further work needs to be done to elucidate upon the use of slags as a source in cement, ceramics and glass industries.

\section{Acknowledgements}

F. Patsiogiannis would like to acknowledge the fellowships Loeb (Spring 1993), Rocca (Fall 1993) and Sidor (Spring-Fall 1994). The authors would like to acknowledge partial financial support of this work from Molten Metal Technology, Inc., Waltham, MA. Benjamin Hellweg, Class of 1997, M.I.T., is acknowledged for preparing the XRD and EMP samples and for translating articles from German. This work made use of MRSEC Shared Facilities supported by the NSF under Award \#DMR-900334. The X-ray powder diffraction was performed under the supervision of $\mathrm{Mr}$. J. Adario and help from Mr. P. Kloumann. The Electron Microprobe was operated by Dr. N. Chatterjee in the Department of Earth, Atmospheric and Planetary Sciences at M.I.T.

\section{REFERENCES}

1) F. Patsiogiannis, M. B. Mourao, U. B. Pal and R. Bogan: EPD Congress 1992, ed. by J. P. Hager, TMS Publication, Warrendale, PA, (1992), 885.

2) F. Patsiogiannis, M. B. Mourao, U. B. Pal and R. S. Bogan: Ironmaking Steelmaking, 20 (1993), 366.

3) F. Patsiogiannis, U. B. Pal and R. Bogan: EPD Congress 1993, ed. by J. P. Hager, TMS Publication, (1993), 605.

4) F. Patsiogiannis, U. B. Pal and R. Bogan: Can. Met. Q., 33 (1994), 305.

5) F. Patsiogiannis, U. Pal and K. C. Chou: Incorporation of Chlorine in a Secondary Steelmaking Slag Based on the $\mathrm{CaO}-\mathrm{Al}_{2} \mathrm{O}_{3}-\mathrm{SiO}_{2}$ System, submitted for publication to ISIJ Int.

6) W. Bussem and A. Eitel: Z. Kristallogr., 95 (1936), 175.

7) V. S. Ramachandran: Applications of Differential Thermal Analysis in Cement Chemistry, Chap. V, Chemical Publishing Co., Inc., New York, (1969), 92.

8) V. K. Singh and F. P. Glasser: Ceramics Int., 14 (1988), 59.

9) A. Derdacka-Grzymek, Z. Konik, J. Iwanciw and A. Stok: $J$. Mat. Sci., 24 (1989), 335.

10) D. R. Uhlmann, P. I. K. Onorato and G. W. Scherer: Proc. Lunar Planet. Sci. Conf. 10th, Pergamon, Oxdord, (1979), 375.

11) E. M. Levin, C. R. Robins and H. F. McMurdie: Phase Diagrams for Ceramist, Compiled at the National Bureau of Standards, ed. and published by The Amer. Ceram. Soc., Columbus, Ohio, (1964), 219.

12) I. Barin, O. Knacke and O. Kubashewski: Thermodynamic Properties of Inorganic Substances, Springer-Verlag, Berlin and New Yrok, NY, (1973), Supplement, (1977), 118.

13) J. S. Machin and T. B. Yee: J. Am. Ceram. Soc., 31 (1948), 200 . 